\title{
Microfibril Angle Characteristics of Korean Pine Trees from Depending on Provinces ${ }^{1}$
}

\author{
Ji-Yeol $\mathrm{KIM}^{2} \cdot$ Soo-Chul $\mathrm{KIM}^{3} \cdot$ Byung-Ro KIM ${ }^{2, \uparrow}$
}

\begin{abstract}
This study investigated the characteristics of microfibril angle(MFA) in order to see if there was any difference in pine tree lumber quality among the three mountain areas surrounding the Taebaek Mountains in Korea - Yeongdong (Goseong-gun), Yeongseo (Hongcheon-gun) and Yeongnam (Bonghwa-gun). Pine trees of each mountain area were divided into earlywood and latewood in relation to heartwood part (1959 1961, 3 annual rings) and sapwood part (2002 2004, 3annual rings), and measured at tangential section. The microfibril angle showed significant differences between mountain areas. In general, Goseong Mountain was found to have $37.35^{\circ}$, followed by Hongcheon Mountain $32.42^{\circ}$ and Bonghwa Mountain $25.75^{\circ}$, in order. The sapwood part had larger angle than heartwood part; and earlywood, than latewood. Variation within a single annual ring tended to be smaller from earlywood toward latewood.
\end{abstract}

Keywords: Korean pine, microfibril angle (MFA), quality characteristics, secondary wall, tangential section

\section{INTRODUCTION}

Pine trees are spread the most extensively in Korea as a fundamental tree species for the forest ecosystem, accounting for about $26 \%$, the widest, of the total national forest area (KRFI, 2016). Morphologically, pine trees generally have a straight stem and, for their excellent lumber quality, have long been utilized as furniture material or building timbers for ancient palaces, temples, etc. According to the investigation on changes in wood species utilized in Korean architectural structures, pine trees are found to have been utilized in most of the structures (Park et al., 2007).
Many traditional wooden architectural craftsmen and concerned persons who deal with Korean pine tree lumbers say that pine trees have different quality depending upon areas. In a survey on any difference in pine tree quality according to areas, about $70 \%$ of the respondents answered there were differences (Han et al., 2015). The cell wall of cells comprising lumber has a laminated structure which can be separated to primary wall and secondary wall. The secondary wall consists of $S_{1}, S_{2}$ and $S_{3}$ layers. Each layer has different microfibril orientation. The microfibril orientation of the thickest layer of secondary wall, $\mathrm{S}_{2}$, has a huge impact on the physical and mechanical properties of

\footnotetext{
${ }^{1}$ Date Received February 3, 2020, Date Accepted June 26, 2020

2 Department of Wood and Paper Science, Chungbuk National University, Cheongju 28644, Republic of Korea

${ }^{3}$ Department of Conservation Science, Korea National University of Cultural Heritage. Buyeo 33115, Republic of Korea

† Corresponding author: Byung-Ro KIM (e-mail: brkim@cbnu.ac.kr, ORCID: 0000-0001-5800-2058)
} 
lumber (KFRI, 2014). Microfibril angle (MFA) refers to the angle between cell axis and microfibril orientation of secondary-wall $S_{2}$ layer. The MFA is one of the important factors evaluating lumber quality (Bergander et al., 2000). Therefore, many related studies have been reported. Oh (1997) reported that compression strength decreased with the increase in the cell height and MFA of uniseriate ray. Eun et al. (2008) studied 3 needleleaf tree species (Pinus densiflora S. et Z., Pinus koraiensis S. et Z., Pinus rigida Mill.) and found that microfibril was larger around the pith part and decreased toward the bark until 15 20 annual rings before it stabilized. Rlee et al. (2005) reported that the microfibril angle was larger in the earlywood part than latewood part while generally showing no significant difference between the south and north sides of the pith. Park et al. (2006), in their study on the variation of material properties of pine tree of superior families, found the microfibril angle range of $9.0 \sim 28.6^{\circ}$, wide differences between families. The studies of pine trees characteristics by region include the physical and mechanical properties of Korean red pine wood from different growth sites and correlations between them (Han et al., 2016), seasonal change of cambium activity of pine trees at different growth sites (Park et al., 2015), establishing local master ring-width chronologies (Oh et al., 2017). In addition, studies on the identification of tree species have compared of cellular anatomical, physical and mechanical properties between Dahurian larch and Japanese larch (Han et al., 2017), effects of density, temperature, size, grain angle of wood materials on non-destructive moisture meters (Pang and Jeong, 2019), performance enhancement of automatic wood classification of Korean softwood by ensembles of convolutional neural networks (Kwon et al., 2019).

The previous research of this present study is the study on the anatomical characteristics of Korean pine trees according to area. The paper found differences in tracheid lengths and diameters according to Yeongdong (Goseong), Yeongseo (Hongcheon) and Yeongnam (Bonghwa) regions (Kim et al., 2018A). Moreover, a study on their physical characteristics reported that pine trees from different areas had different shrinkage, and the lateral shrinkage and tracheid length had a proportional relationship (Kim et al., 2018B).

This present study, building on the studies on the anatomical and physical characteristics of pine trees according to their areas of growth, seeks to investigate pine-tree microfibril angle to see if there is any difference according to their places of growth and analyze the relationship with the anatomical and physical characteristics in order to identify lumber quality characteristics depending upon areas.

\section{MATERIALS and METHODS}

\subsection{Materials}

Pine trees from Yeongdong (Goseong), Yeongseo (Hongcheon) and Yeongnam (Bonghw) retained in the Forestry Association's East Sea Distribution Center were transferred in 2015 for this study experiment. This is the same disk as previous studies of this study, Kim et al. (2018A) and Kim et al. (2018B). At the point of transfer, they were in a disk form with the thickness of about $20 \mathrm{~cm}$ (Fig. 1). Table 1 exhibits their tree rings, chest diameter, average annual ring width, latewood proportion and tree trimming year.

\subsection{Methods}

\subsubsection{Microfibril angle measurement}

Specimens were made with the disks from the three places in the size of $1.5 \times 1.5 \times 1.5 \mathrm{~cm}$ including the heartwood part (1959 1961, 3 annual rings) and sapwood part (2002 2004, 3 annual rings). The 
Table 1. Information on experimental samples

\begin{tabular}{cccccc}
\hline Province & $\begin{array}{c}\text { No. of } \\
\text { Tree ring }\end{array}$ & $\begin{array}{c}\text { Diameter } \\
(\mathrm{cm})\end{array}$ & $\begin{array}{c}\text { Average annual ring } \\
\text { width }(\mathrm{cm})\end{array}$ & $\begin{array}{c}\text { Latewood } \\
\text { ratio (\%) }\end{array}$ & $\begin{array}{c}\text { Tree trimming } \\
\text { year }\end{array}$ \\
\hline \hline Goseong & 85 & 48 & 3.1 & 22.87 & 2013 \\
Hongcheon & 82 & 42 & 2.6 & 20.19 & 2012 \\
Bonghwa & 76 & 45.5 & 3.1 & 18.57 & 2014 \\
\hline
\end{tabular}

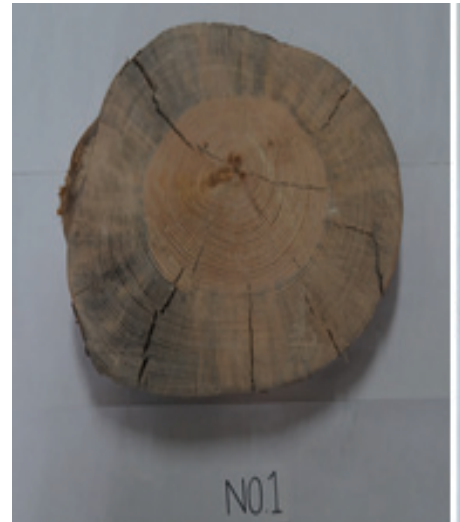

Goseong

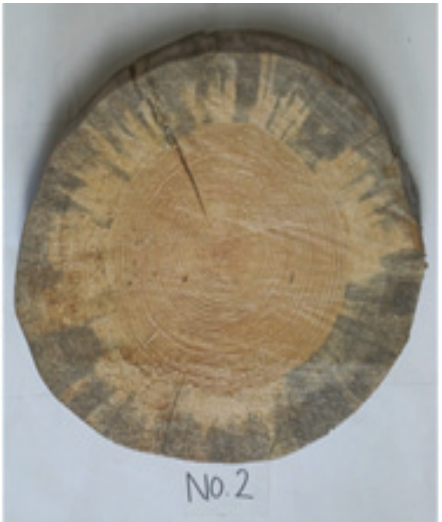

Hongcheon

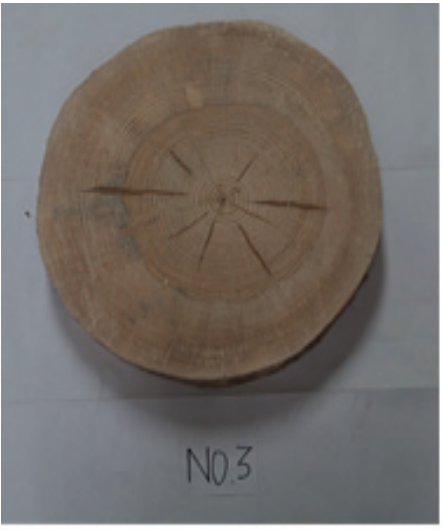

Bonghwa

Fig. 1. Disks from each province.

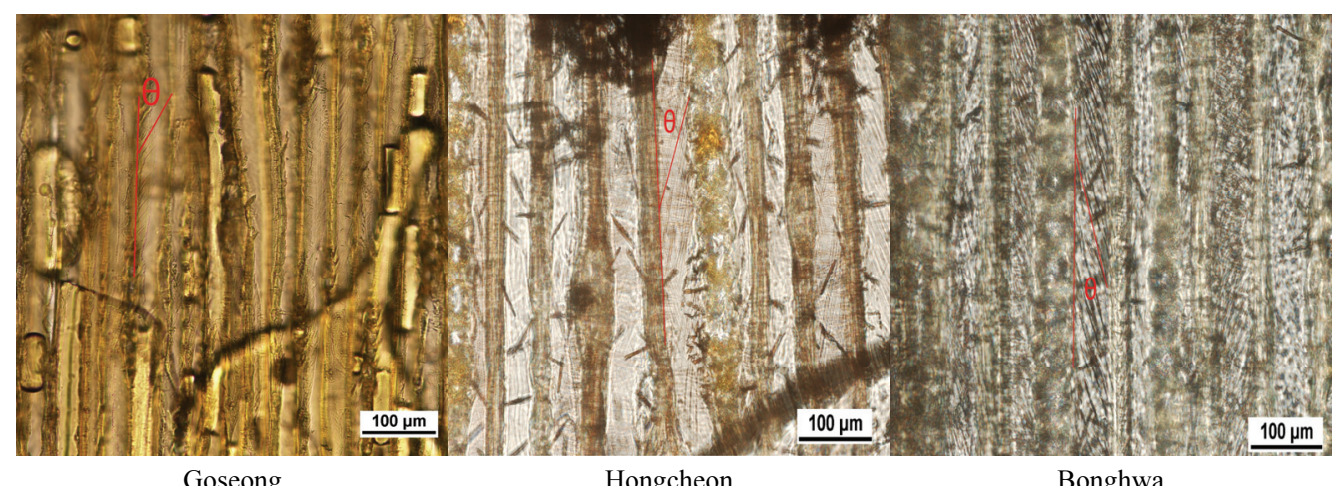

Fig. 2. Microfibril angle $\left(\Theta={ }^{\circ}\right)$ on heartwood of each province.

specimens were softened and divided into earlywood and latewood at each annual ring to make 3 tangential section pieces each in the thickness of $20 \sim 24 \mu \mathrm{m}$ using Microtome. The sample pieces were soaked into Schultze, dehydrated using alcohol series $(10,30,60$, $80,100 \%$, and placed on the slide glass to process using 3 4\% iodine-potassium iodide. Then, $50 \%$ ni- tric acid was dropped to form needle crystal and make permanent preparation using permount (Park et al., 1993). They were observed with multimedia image microscope (Ni KON JP/E cl 1 paa 801), then, 45 microfibril angles were filmed and measured on each slide using NIS (NIS-E lements BR 4.50 .00 64-bit) program (Fig. 2). 


\subsubsection{Microfibril angle variation within single annual ring}

Three sample pieces were made each in earlywood and latewood within 1 annual ring of heartwood and sapwood from three mountain areas, and the microfibril angle variation in a single annual ring was investigated.

\section{RESULTS and DISCUSSION}

\subsection{Characteristics of microfibril angle}

Table 2 shows the heartwood part and sapwood part of pine trees from the three areas and microfibril angle of their earlywood and latewood. The average of area-specific microfibril-angle heartwood part and sapwood part and their earlywood and latewood was $37.35^{\circ}$, the highest, for those from Goseong Mountain, followed by Hongcheon Mountain with $32.42^{\circ}$, and Bonghwa Mountain, $25.75^{\circ}$, the smallest (Table 2). In terms of heartwood part and sapwood part, all the three mountain areas had larger microfibril angle in sapwood part than heartwood part. With respect to earlywood and latewood, the three places showed larger microfibril angle in earlywood than latewood. Eun et al. (2008) reported in their study on microstructure variation in the stem of main Korean needleleaf woods that microfibril angle was the largest at the pith of pine tree and declined until $15 \sim 20$ annual rings along the annual ring increase towards the bark before stabilizing; and microfibril angle also decreased as a tree grew from juvenile wood to mature wood. Lee et al. (2015) studied the characteristics of yellowhearted pine and reported that microfibril angle at the pith part (21 annual rings) was $35 \sim 40^{\circ}$; mid part (81 annual rings), $25 \sim 30^{\circ}$; and bark part (141 annual rings), $20 \sim 35^{\circ}$; and the angle grew smaller towards the bark part. This present study found microfibril angles growing wider towards the bark (sapwood part) from pith (heartwood part) in all of the three places, showing difference from the findings by Eun et al. (2008), Lee (2016) and Lee et al. (2015). Additional investigation seems necessary in this regard. As preceding studies such as Kim et al. (1998), Lee et al. (2015), KFRI (2014), and Eun et al. (2008), this present study also reported that latewood microfibril angle was smaller than earlywood angle, indicating the same results in this study as well.

Table 2 is also about Duncan test using IBM SPSS Statistics 24 to examine if there was any difference in microfibril angle of earlywood and latewood as well as heartwood part and sapwood part of pine trees from the three areas. In the heartwood part, the earlywood of Goseong Mountain had 36.56 ; Hongcheon Mountain, $33.31^{\circ}$; and Bonghwa Mountain, $24.61^{\circ}$; and the

Table 2. Microfibril angle of each province

\begin{tabular}{|c|c|c|c|c|c|c|}
\hline \multirow{2}{*}{$\operatorname{MFA}\left({ }^{\circ}\right)$} & \multicolumn{2}{|c|}{ Goseong } & \multicolumn{2}{|c|}{ Hongcheon } & \multicolumn{2}{|c|}{ Bonghwa } \\
\hline & Earlywood & Latewood & Earlywood & Latewood & Earlywood & Latewood \\
\hline Heartwood & $\begin{array}{c}\mathrm{A}^{*} \\
36.56 \pm 0.42\end{array}$ & $32.59^{\mathrm{a}} \pm 0.72$ & $\begin{array}{c}\mathrm{B} \\
33.31 \pm 1.23\end{array}$ & $26.25^{b} \pm 2.57$ & $24.61^{\mathrm{C}} \pm 1.82$ & $21.14^{\mathrm{c}} \pm 2.00$ \\
\hline Sapwood & $\underset{41.45 \pm 2.53}{\mathrm{~A}}$ & $38.78^{\mathrm{a}} \pm 2.32$ & $\begin{array}{c}\mathrm{A} \\
37.98 \pm 1.42\end{array}$ & $32.13^{\mathrm{b}} \pm 1.43$ & $30.93 \pm 1.18$ & $26.27^{\mathrm{c}} \pm 0.36$ \\
\hline Average & \multicolumn{2}{|c|}{$\frac{I}{3735 \pm 1016}$} & \multicolumn{2}{|c|}{ II } & \multicolumn{2}{|c|}{$\underset{25.75 \pm 7.24}{\text { III }}$} \\
\hline
\end{tabular}

\footnotetext{
* The same letters indicate no significant difference by Duncan's multiple test at 0.05 level. Earlywood $=$ Capital letter, Latewood $=$ Small letter, Average $=$ Roman numerals.
} 
latewood of Goseong Mountain had 32.59\%; Hongcheon Mountain, 26.25 ; and Bonghwa Mountain, $21.14^{\circ}$. In the sapwood part, the earlywood of Goseong Mountain had $41.45^{\circ}$; Hongcheon Mountain, 37.98 ; and Bonghwa Mountain, 30.93 ${ }^{\circ}$; and the latewood of Goseong Mountain was 38.78 ; Hongcheon Mountain, 32.13; and Bonghwa Mountain, 26.27 ${ }^{\circ}$, indicating Goseong Mountain was the largest, followed by Hongcheon Mountain and Bonghwa Mountain in order. Statistical processing was implemented to see if there was any difference between them. As a result, significant differences were observed among the three areas in general, excepting the earlywood of sapwood part, which showed no significant difference between Goseong Mountain and Hongcheon Mountain.

In the previous study on the anatomical characteristics of the three mountain areas, the tracheid length was measured by separating the heartwood part (1955 1964) and sapwood part (2002 2011). The study reported that the measurements were found the largest in trees from Bonghwa Mountain, followed by Hongcheon Mountain and Goseong Mountain in order (Kim et al., 2018A). In terms of the relationship between the tracheid lengths above and microfibril angles of this present study; the longer the tracheid lengths, the narrower the microfibril angles were found. Kim et al. (1998), KFRI (2014), Rlee et al. (2005), Hiller (1964), Mark (1967), Preston (1952), Wellwood (1962), Wadanabe et al. (1964) and others reported a negative correlation between tracheid length and microfibril angle as microfibril angle grew narrower, tracheid length was longer and the angle was wider as tracheid length was shorter. In the preceding study on the physical characteristics of trees from the three mountain areas, shrinkage from green to air dry and shrinkage from green to ovendry were measured in the tangential direction. The shrinkage from green to air dry of Goseong Mountain was $2.86 \%$; Hongcheon Mountain, 3.94 \%; and Bonghwa Mountain, $4.39 \%$.
The shrinkage from green to ovendry of Goseong Mountain was $6.32 \%$; Hongcheon Mountain, $6.58 \%$; and Bonghwa Mountain, $9.85 \%$, indicating that both conditions had the largest measurement in trees from Bonghwa Mountain, followed by Hongcheon Mountain and Goseong Mountain (Kim et al., 2018B). In terms of the relationship between the shrinkage above and microfibril angle of this present study; the larger the shrinkage from green to air dry and shrinkage from green to ovendry, the narrower the microfibril angle was found. Barber et al. (1964) and Kim et al. (1998) reported that, as microfibril angle increased, longitudinal shrinkage rose; and, as the former decreased, lateral shrinkage increased. Therefore, of the physical characteristics found by Kim et al. (2018B), differences between mountain areas seem to have been caused by tracheid length (Kim et al., 2018A) and microfibril angle of this present study. Such differences seem to be due to each mountain area's topography, soil, climate, etc. Study related to this aspect will need to be implemented in the future as well.

\subsection{Microfibril angle variation within single annual ring}

Fig. 3 exhibits microfibril angle variations within a single annual ring of the heartwood part and sapwood part of pine trees from Goseong Mountain, Hongcheon Mountain and Bonghwa Mountain. All the three mountain areas showed smaller angle variations from earlywood to latewood. Lee et al. (2015), in their study on the quality characteristics of yellow-hearted pine, round that, in a single annual ring, microfibril angles were larger in earlywood than latewood. The researchers also measured earlywood and latewood microfibril angles in 21 and 51 annual rings and found that earlywood was $28.26^{\circ}$; and latewood, $25.75^{\circ}$, demonstrating angles narrowing from earlywood to latewood. Chun et al. (1983), in the study on microfibril angle of lumbar cell wall, reported that the 


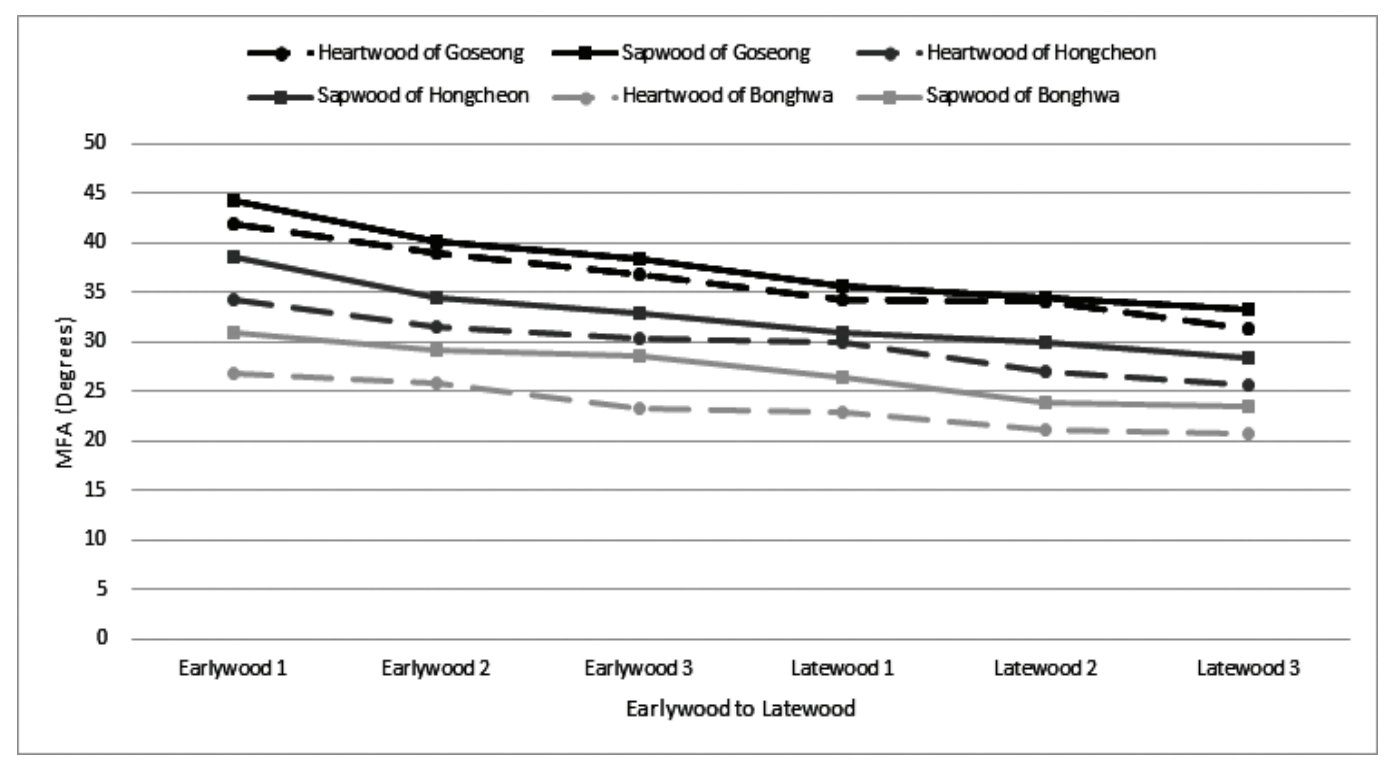

Fig. 3. Variation of microfibril angle within 1 annual ring of each province.

microfibril angles of normal nut-tree lumbar stem averaged $17.6^{\circ}$; earlywood part, $19.8^{\circ}$; and latewood part, $15.3^{\circ}$, finding larger angles in earlywood than latewood, consistently with this present study.

\section{CONCLUSION}

In this present study, microfibril angle characteristics were examined in order to see if there was any difference in pine tree quality depending upon their growth areas - Yeongdong (Goseong), Yeongseo (Hongcheon) and Yeongnam (Bonghwa) surrounding the Taebaek Mountains. The microfibril angles showed difference according to areas. In terms of the heartwood and sapwood parts and their earlywood and latewood, Goseong Mountain was measured to have

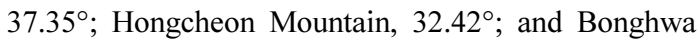
Mountain, $25.75^{\circ}$ in general. In the comparison between heartwood and sapwood part, the sapwood part showed larger measurement than heartwood part. Between earlywood and latewood, the earlywood had bigger angles than latewood. Variation in a single annual ring was found narrower from earlywood to latewood. Microfibril angles with regional difference were found to have an impact on a physical property (shrinkage) together with the anatomical characteristic (tracheid length).

\section{ACKNOWLEDGMENT}

This research was supported by Chungbuk National University (2018-2019).

\section{REFERENCES}

Barber, N.F., Meylan, B.A. 1964. The anisotropic shrinkage of wood. Holzforschung 18(5): 146-156.

Bergander, A., Salmén, L. 2000. Variations in transverse fibre wall properties: Relations between elastic properties and structure. Holzforschung 54(6): 654-660.

Chun, S.K., Lee, W.Y. 1983. Studils on micro fibril 
angle of woody plant cell wall (1): Variation of micro fibril angle on tree stem. Journal of the Korean Wood Science and Technology 11(5): 5-11.

Eun, D.J., Kim, N.H. 2008. Variation of microfibril angle within stems of three commercial softwoods grown in Korea. Journal of the Korean Wood Science and Technology 36(4): 77-83.

Eun, D.J. 2008. Variation of fine structures within stems of three commercial softwoods grown in Korea. Master Thesis, Kangwon University, korea

Han, G.S. 2015. Study on improvement site management system and supply system of timber for repairing culture properties. Cultural Heritage Administration. Daejeon Korea.

Han, Y.J., Kim, M.J., Lee, H.M., Kang, J.T., Eom, C.D. 2017. Comparison of cellular anatomical, physical and mechanical properties between dahurian larch and Japanese larch. Journal of the Korean Wood Science and Technology 45(5): 525-534.

Han, Y.J., Lee, H.M., Eom, C.D. 2016. Physical and mechanical properties of korean red pine wood from different growth sites and correlations between them. Journal of the Korean Wood Science and Technology 44(5): 695-704.

Hiller, C.H. 1964. Pattern of variation of fibril angle within annual rings of Pinus attenuradiata. Res. Note FPL-034, U.S. Department of Agriculture, Forest Service, Forest Products Laboratory, Madison, Wisconsin.

Kim, M.J., Kim, B.R. 2018B. Physical characteristics of Korean red pines according to provinces (Goseong, Hongcheon and Bonghwa-gun). Journal of the Korean Wood Science and Technology 46(5): 437-448.

Kim, M.J., Seo, J.W., Kim, B.R. 2018A. Anatomical characteristics of Korean red pines cording to provinces. Journal of the Korean Wood Science and Technology 46(1): 100-106.

Kim, B.R. 1998. Studies on variability of wood pro- perties in stem of Pinus koraiensis (III): Variations in tracheid length and width, microfibril angle and compression strength in the longitudinal direction. Conference Proceedings of the Korean Wood Science and Technology, pp. 55-61.

Korea Forest Research Institute. 2014. Measurement of microfibril angle and shrinkage of wood utilizing light microscopy. Research Report 2014. Korea Forest Research Institute, Seoul, Korea.

Korea Forest Research Institute. 2016. Preservation and management system of Korea red pine and Korea red pine forest in Korea. Research Report 2016. Korea Forest Research Institute, Seoul, Korea.

Kwon, O.K., Lee, H.G., Yang, S.Y., Kim, H.B., Park, S.Y., Choi, I.G., Yeo, H.M. 2019. Performance enhancement of automatic wood classification of Korean softwood by ensembles of convolutional neural networks. Journal of the Korean Wood Science and Technology 47(3): 265-276.

Lee, M.R., Park, J.H., Park, Y.G., Yang, S.Y., Jang, Y.S., Eom, C.H., Park, J.H., Seo, J.G., Yeo, H.M., Kwon, O.K. 2015. Growth area and microfibril angle analysis of pine. 2015 Proceedings of the Korean Society of Wood Science and Technology Annual Meeting, pp. 192-193.

Lee, A.H., Sugiyama, J., Jang, J.H., Kim, N.H. 2015. Radial variation of microfibril angle of yellowhearted pine. 2015 Proceedings of the Korean Society of Wood Science and Technology annual meeting, pp. 198-199.

Lee. A.H. 2016. Wood quality of Yellow-hearted pine (Pinus densiflora for. erecta Uyeki). Master Thesis, Kangwon University, korea.

Mark, R.E. 1967. Cell wall mechanics of tracheids. Yale Univ. Press, New Haven and London. National Institute of Forest Science.

Oh, J.A., Seo, J.W., Kim, B.R. 2017. Establishing local master ring-width chronologies and their utilization for estimating the age of big old trees. Journal of 
the Korean Wood Science and Technology 45(1): 85-95.

Oh, S.W. 1997. Relationship between compression strength parallel to grain and anatomical characters in Pinus densiflora S. et. Z.. Journal of the Korean Wood Science and Technology 25(2): 27-32.

Pang. S.J., Jeong, G.Y. 2019. Effects of density, temperature, size, grain angle of wood materials on nondestructive moisture meters. Journal of the Korean Wood Science and Technology 47(1): 40-50.

Park, S.J., Lee. J.Y., Cho. N.S., Cho. B.M. 1993. Wood science experiment book. Gwangil munhwasa, Seoul, Korea.

Park, B.S., Park, J.H., Han, S.U. 2006. Variation of material properties of Korean red pine of superior families. Journal of the Korean Forest Energy 25(2): 9-15.

Park, S.Y., Eom, C.D., Seo, J.W. 2015. Seasonal change of cambium activity of pine trees at different growth sites. Journal of the Korean Wood Science and Technology 43(4): 411-420.

Park, W.K., Lee, K.H. 2007. Changes in the species of woods used for Korean ancient and historic architectures, Korean Association of Architectural History 50(1): 9-28.
Preston, R.D. 1952. The molecular architecture of plant cell walls. Chapman and Hall. London p. 116.

Rlee, S.M., Kim, B.R. 2005. Studies on variability of wood properties within stem of Larix kaemferi (2): Difference in tracheid length and width, microfibril angle, and strength in south and north sides of stem. Journal of the Korean Wood Science and Technology 33(1): 21-28.

Seo, J.W., Eom, C.D., Park, S.Y. 2014. Study on the variations of inter-annual tracheid length for Korean red pine from Sokwang-ri in Uljin. Journal of the Korean Wood Science and Technology 42(6): 646-652.

Wardrop, A.B. 1965. Cellular differentiation in xylem. In: Cellular ultrastructure of woody plants. W. A. Cote, ed. Syracuse University Press, Syracuse, NY., pp. 61-97.

Watanabe, H., Tsutsumi, J., Matsumoto, T., Ohta, S. 1964. Studies on juvenile wood. II. On distribution of specific compression strength and specific modulus of elasticity in st em of sugi tree (Crytomeria japonica D. Don). Mokazai Gakkaishi 10(4): 125-130.

Wellwood, R.W. 1962. Tensile testing of small wood sample. Pulp and Paper Magazine of Canada 6361. 